\title{
Aktivitas Vasodilatasi Pembuluh Darah secara in vitro dan Uji Toksisitas Akut Minuman Fungsional Herbal Kaltim
}

\author{
Sjarif Ismail ${ }^{1}$ dan Yuniati $^{\mathbf{2}}$ \\ ${ }^{1}$ Laboratorium Farmakololog Universitas Mulawarna, Samarinda, Kalimantan Timur \\ ${ }^{2}$ Laboratorium Mikrobioloogi, Universitas Mulawarman, Samarinda, Kalimantan Tr \\ emaili: ismail8997@yahoo.com
}

\begin{abstract}
Abstrak
Latar belakang: pangan fungsional dapat berupa makanan atau minuman. Pangan fungsional lebih bersifat pencegahan terhadap penyakit, sedangkan obat lebih bersifat menyembuhkan penyakit. Minuman Fungsional Herbal Kaltim (MFHK) yang diracik dari bahan-bahan tumbuhan yang ada di Kaltim telah diketahui memiliki citra rasa yang enak dan memiliki aktivitas antioksidan yang kuat tetapi belum diketahui aktivitas vasodilatasi pada pembuluh darah dan keamanan pada penggunaan akut secara oral. Tujuan: mengeksplorasi MFHK pada kontraktilitas tonus pembuluh darah secara in vitro dan keamanan pada penggunaan akut secara oral. Metode: MFHK dikeringkan lalu diuji kontraktilitas pada pembuluh darah dengan menggunakan organ terpisah aorta tikus dengan endotel, hasil dinyatakan dalam bentuk persen tonus kontraktilitas aorta. Uji toksisitas akut peroral menggunakan tikus Wistar dan mencit Balb/c jenis kelamin jantan dan betina. Hasil: pada uji kontraktilitas aorta didapatkan secara berurutan dalam persen tonus kontraktilitas aorta pada konsentrasi ekstrak MFHK $0,04 \mathrm{mg} / \mathrm{mL}$ adalah $(1,02 \pm$ $1,43) \%$ dan kontrol $(3,27 \pm 1,00) \%$ dengan $p>0,05$; pada $0,08 \mathrm{mg} / \mathrm{mL}$ didapatkan $(-1,39 \pm$ $1,41) \%$ dan $(4,50+1,14) \%$ dengan $p<0,05 ; 0,16 \mathrm{mg} / \mathrm{mL}$ didapatkan $(-5,36+1,40) \%$ dan $(8,42 \pm 2,00) \%$ dengan $p<0,05$. Dosis tunggal ekstrak $2 \mathrm{~g} / \mathrm{kgBB}$ yang diberikan secara oral tidak didapatkan kematian pada tikus dan mencit jenis kelamin jantan dan betina. Kesimpulan: ekstrak MFHK memiliki aktivitas vasodilatasi pada pembuluh darah secara in vitro dan tidak toksik pada pemberian akut secara oral.
\end{abstract}

Kata kunci: Minuman Fungsional Herbal Kaltim - Vasodilatasi - Toksisitas Akut

\section{PENDAHULUAN}

Istilah pangan fungsional muncul karena pemilihan bahan pangan tidak hanya berdasarkan nilai gizi, rasa enak, bentuk menarik, tetapi harus juga berpengaruh baik terhadap kesehatan tubuh. Pangan fungsional dapat berupa makanan atau minuman. Pangan fungsional lebih bersifat pencegahan terhadap penyakit, sedangkan obat lebih bersifat menyembuhkan penyakit ${ }^{1}$. Kalimantan Timur kaya akan keanekaragaman tumbuhan dan terdiri dari banyak etnis dayak dengan kearifan lokal menggunakan tanaman obat disekitarnya. Minuman Fungsional Herbal Kaltim (MFHK) yang diracik dari berbagai tumbuhan yang berasal dari Kalimantan Timur telah diketahui memiliki aktivitas antioksidan yang kuat dan memiliki citra rasa yang enak ${ }^{2}$. Salah satu bahan yang terkandung dalam MFHK adalah daun Dracontomelon dao dan batang Fibraurea tinctoria yang sudah diketahui dalam bentuk ekstrak memiliki aktivitas vasodilatasi secara in vitro $3,4,5$, tetapi dalam bentuk ramuan MFHK masih belum diketahui aktivitas vasodilatasi pada pembuluh darah secara 
in vitro dan toksisitas akut pada penggunaan secara oral.

\section{METODE PENELITIAN}

\section{Bahan}

Minuman Fungsional Herbal Kaltim berasal dari Laboratorium Farmakologi FK-UNMUL, larutan Kreb's-Henselheit, $\mathrm{KCl}, \quad$ fenilefrin, asetilkolin, akuades.

\section{Peralatan}

Freeze dry, dissecting set, mikroskop, $\mathrm{pH}$ meter, isolated organ bath dua chamber, octal bridge amplifier, pencatat digital Power Lab/16SP, transducer isometrik.

\section{Hewan Uji}

Tikus Wistar berat 200-220 gram dan mencit Balb/c berat 24-27 gram berasal dari Laboratorium Farmakologi FK-UNMUL, jenis kelamin jantan dan betina. Hewan dipelihara sesuai standar etik yang berlaku di FK-UNMUL. Pencahayaan sinar matahari pada siang dan gelap pada malam, makan dan minum secara ad libitum, suhu ruangan dipertahankan dengan menggunakan AC pada suhu $22-24{ }^{\circ} \mathrm{C}$. Sebelum penelitian dimulai, hewan uji diaklimasi selama satu minggu. Protokol penelitian ini menggunakan hewan uji yang sudah disetujui oleh Komisi Etik Penelitian Fakultas Kedokteran Universitas Mulawarman.

\section{Prosedur}

\section{Pengeringan MFHK} MFHK dipekatkan menggunakan freeze dry kemudian dikeringkan lebih lanjut dalam desikator yang menggandung silika gel biru yang dimasukan dalam oven suhu $70{ }^{\circ} \mathrm{C}$ selama satu minggu. MFHK yang sudah kering ditimbang dan dinamakan ekstrak MFHK.

\section{Uji kontraktilitas tonus pembuluh darah secara in vitro \\ Uji kontraktilitas tonus} pembuluh darah digunakan organ terpisah aorta tikus dengan endotel seperti yang dideskripsikan oleh Dong \& Ki (1996) dan Vercruysse et al., (2008) 6,7 , digunakan aorta thorakalis yang dipotong melintang selebar $3 \mathrm{~mm}$ dan dinamakan cincin aorta dengan endotel. Organ bath yang digunakan $10 \mathrm{~mL}$ dan tonus basal 2 g. Uji respon kontraksi aorta digunakan larutan $\mathrm{KCl} 60 \mathrm{mM}$. Setelah dibilas tiga kali setiap 15 menit dengan larutan Kreb's-Henselheit sampai kembali ke basal dilanjutkan dengan uji integritas endotel. Cincin aorta dengan endotel diprekontraksi dengan larutan fenilefrin $10^{-5} \mathrm{M}$, dinyatakan aorta dengan endotel jika respon vasodilatasi lebih dari $60 \%$ setelah pemberian asetilkolin $10^{-4} \mathrm{M}$.

Setelah pengujian respon kontraksi aorta dan integritas endotel, aorta dibilas dengan larutan Kreb'sHenselheit sebanyak tiga kali setiap 15 menit sampai mencapai tonus basal dan siap untuk dilakukan uji aktivitas vasodilatasi. Pada uji aktivitas vasodilatasi, aorta dikontraksikan dengan larutan fenilefrin $10^{-5} \mathrm{M}$, setelah mencapai puncak kontraksi yang datar diberikan ekstrak MFHK dengan dosis kumulatif sebanyak tiga konsentrasi. Sebagai kontrol negatif digunakan pelarut ekstrak. Pengulangan dilakukan enam kali dan hasil dinyatakan dalam persen tonus aorta. Persen tonus kontraktilitas aorta adalah nilai tonus aorta setelah pemberian ekstrak/kontrol dikurangi tonus aorta setelah pemberian fenilefrin lalu dibagi dengan tonus aorta setelah pemberian fenilefrin. Hasil yang negatif dari nilai persen tonus kontraktilitas pembuluh darah menunjukkan aktivitas vasodilatasi pada pembuluh darah. 


\section{Uji toksisitas akut}

Uji toksisitas akut dilakukan pada mencit Balbc dan tikus Wistar, jenis kelamin jantan dan betina masing-masing 10 ekor secara step Down seperti yang dideskripsikan oleh AOCD. Hewan dimasukan dalam kandang secara individual. Ekstrak MFHK diberikan secara oral dengan dosis tunggal $2 \mathrm{~g} / \mathrm{kgbb}$ menggunakan sonde lambung, kemudian diamati tingkah laku hewan dan jumlah kematian selama satu minggu, jika terjadi kematian dosis diulang setengahnya dan hewan yang mati langsung di otopsi untuk diketahui penyebab kematian hewan uji.

Tabel 1 Persen tonus kontraktilitas aorta terhadap pemberian ekstrak MFHK pada organ terpisah aorta tikus dengan endotel utuh

\begin{tabular}{|c|c|c|c|c|c|c|c|c|}
\hline \multirow{3}{*}{$\begin{array}{c}\text { Jenis } \\
\text { Perlakuan }\end{array}$} & \multicolumn{8}{|c|}{$\begin{array}{l}\text { Persen Tonus Kontraktilitas Aorta pada Pemberian } \\
\text { Ekstrak MFHK Konsentrasi }\end{array}$} \\
\hline & \multicolumn{2}{|c|}{$0,04 \mathrm{mg} / \mathrm{mL}$} & \multicolumn{3}{|c|}{$0,08 \mathrm{mg} / \mathrm{mL}$} & \multicolumn{3}{|c|}{$0,16 \mathrm{mg} / \mathrm{mL}$} \\
\hline & Mean & $\pm \mathrm{SD}$ & Mean & \pm & SD & Mean & \pm & SD \\
\hline Kon & 3,27 & $\pm 1,00$ & 4,50 & \pm & 1,14 & 8,42 & \pm & 2,00 \\
\hline MFHK & 1,02 & $\pm \quad 1,43$ & $-1,39$ & \pm & $1,41 *$ & $-5,36$ & \pm & $1,40^{*}$ \\
\hline
\end{tabular}

Keterangan: $n=6$ ekor tikus. Konsentrasi diatas merupakan konsentrasi ekstrak dalam organ bath $10 \mathrm{ml}$. Sebagai kontrol digunakan akuades. * Uji statistik dengan tes- $t$ berbeda bermakna dengan $p<0,05$.

\section{HASIL DAN PEMBAHASAN}

\section{Hasil pemekatan MFHK} didapatkan rendemen $0,239(\mathrm{~b} / \mathrm{v})$. Hasil uji kontraktilitas pembuluh darah didapatkan bahwa ekstrak MFHK yang dimasukan dalam organ bath dapat menyebabkan penurunan persen tonus kontraktilitas aorta yang semakin meningkat dengan peningkatan konsentrasi ekstrak yang dimasukan pada organ bath yang berisi aorta tikus dengan endotel dengan hasil seperti yang terlihat pada Tabel diatas. Hasil penelitian ini memperlihatkan bahwa ekstrak MFHK memiliki aktivitas vasodilatasi pada pembuluh darah. Pada kontrol digunakan akuades tampak terjadi peningkatan persen tonus aorta jika konsentrasi ditingkatkan.

Hasil uji toksisitas akut dengan pemberian dosis tunggal $2 \mathrm{~g} / \mathrm{kg}$ bb secara oral pada tikus dan mencit dengan jenis kelamin jantan dan betina tidak dijumpai perubahan tingkah laku dan kematian pada hewan uji setelah diamati selama satu minggu. Hal ini menandakan ekstrak
MFHK tidak toksik pada penggunaan secara akut per oral.

Vasodilatasi pembuluh darah diperantarai oleh: (1) endotel melalui pelepasan NO lalu mengaktivasi soluble guanylyl siklase (sGC) selanjutnya terjadi modulasi ion kalsium di otot polos pembuluh darah, atau (2) secara langsung pada otot polos pembuluh darah. Pada endotel terdapat berbagai reseptor seperti reseptor muskarinik M2 (asetil kolin), reseptor histamin $\mathrm{H} 2$ (histamin), reseptor vasopressin (arginin vasopressin), reseptor adrenergic- $\alpha 2$ (adrenalin dan nor adrenalin), reseptor 5hidroksitriptamin/serotonin (5-HT1), reseptor kinin (bradikinin), reseptor purinergik (ADP), reseptor trombin (trombin), reseptor endotelin (endotelin) ${ }^{8}$. Setelah terjadi interaksi antara reseptor tersebut dengan agonis di sel endotel akan menyebabkan peningkatan ion kalsium di sitosol dan pelepasan NO, selanjutnya difusi ke otot polos pembuluh darah. Pada otot polos pembuluh darah, NO mengaktivasi sGC. Aktivasi sGC menyebabkan peningkatan cGMP. 
Aktivasi cGMP-dependent protein kinases menyebabkan inhibisi hidrolisis phosphatidil inositol 4,5 bifosfat $\left(\mathrm{PIP}_{2}\right)$ menjadi inositol 1,4,5 trifosfat $\left(\mathrm{IP}_{3}\right)$ pada otot polos aorta, peran $\mathrm{IP}_{3}$ adalah menginduksi pelepasan ion kalsium ${ }^{9,10}$.

Peningkatan ion kalsium di sitosol otot polos pembuluh darah menyebabkan interaksi ion kalsium dengan kalmodulin sehingga terjadi kompleks kalsium-kalmodulin. Kompleks ini selanjutnya berikatan dengan myosin light chain kinases (MLCK) untuk membentuk enzim kompleks kalsiumkalmodulin-MLCK yang aktif. Kompleks aktif enzim ini menyebabkan fosforilasi pada myosin light chain sehingga terjadi penempelan thick filament head pada aktin. Fosforilasi ini membutuhkan satu ATP untuk mengontrol hubungan aktinmyosin dalam terjadinya kontraksi otot. Jika kalsium di sitosol menurun maka aktivitas kompleks kalmodulin-ion kalsium akan menurun, sehingga MLCK yang mengaktivasi miosin ATP-ase akan menurun, maka kepala miosin akan lepas dari aktin sehingga terjadi vasodilatasi pada pembuluh darah ${ }^{8,9,10}$.

Aktivitas vasodilatasi pada pembuluh darah secara in vitro pada ekstrak MFHK disebabkan oleh keberadaan komponen daun Dracontomelon dao dan batang Fibraurea tinctoria yang sudah dibuktikan memiliki aktivitas vasodilatasi. Pada daun Dracontomelon dao telah diteliti mengandung metabolit sekunder polifenol dan flavonoid ${ }^{11}$. Metabolit sekunder polifenol dan flavonoid mungkin berperan sebagai vasodilator pada pembuluh darah karena resveratrol yang di isolasi dari biji anggur termasuk kelompok polifenol dan icarin yang diisolasi dari herba Epimedii termasuk kelompok metabolit sekunder flavonoid telah diketahui memiliki aktivitas vasodilatasi pada pembuluh darah 12,13. Pada batang Fibraurea tinctoria telah diteliti mengandung metabolit sekunder alkaloid dan mungkin berperan sebagai vasodilator pada pembuluh darah karena rutaecarpin merupakan metabolit sekunder alkaloid yang di isolasi dari Evodia rutaecarpa memiliki aktivitas vasodilatasi pada pembuluh darah ${ }^{14}$.

Hasil penelitian ini jika dibandingkan dengan penelitian terdahulu pada fraksi metanol daun Dracontomelon dao dengan konsentrasi yang sama didapatkan persen kontraktilitas tonus aorta pada pemberian MFHK lebih lemah dan mencapai lebih dari setengahnya 5 . Hal ini mungkin disebabkan metabolit sekunder yang dapat diekstraksi pada waktu digodok lebih sedikit dibandingkan dengan ekstraksi dengan pelarut organik seperti metanol meskipun komposisi daun Dracontomelon dao dalam MFHK mencapai lebih dari $70 \%$, untuk membuktikan hal ini diperlukan penelitian lebih lanjut.

Uji toksisitas akut perlu dilakukan untuk membuktikan keamanan MFHK sebelum dipasarkan dan dilakukan uji klinik khasiat sebagai vasodilator (memperlancar sirkulasi darah dan antihipertensi) antioksidan. Berdasarkan peraturan dari Kemenkes, suatu jamu baru bisa didaftarkan bila telah lolos uji toksisitas akut pada hewan uji dan uji praklinik.

\section{KESIMPULAN}

Ekstrak MFHK telah dibuktikan memiliki aktivitas vasodilatasi pada pembuluh darah secara in vitro dan tidak toksik pada pemberian akut secara oral.

\section{UCAPAN TERIMAKASIH}

Seluruh penelitian ini dibiayai dari dana Hibah dalam skim Penelitian Hibah Bersaing Kemendikbud Tahun 2014 dan 2015.

\section{DAFTAR PUSTAKA}

1. Sampoerno dan Fardiaz, D. 2001. Kebijakan dan pengembangan pangan fungsional dan suplemen di 
Indonesia. Dalam I. Nuraida dan R. D. Hariyadi (editor). Pangan Tradisional Basis Bagi Industri Pangan Fungsional dan Suplemen. Pusat Kajian Makanan Tradisional, Institut Pertanian Bogor. Page 1-15.

2. Ismail, S., and Yuniati. 2014. Aktivitas antioksidan tumbuhan obat Kaltim sebagai minuman fungsional. Prosiding Simposium Penelitian Bahan Obat Alami (SPBOA) XVI dan Muktamar XII PERHIPBA 2014, Cetakan Pertama, Leutikaprio. Page 130-134.

3. Ismail, S. 2011. Presentasi oral Kajian toksisitas akut dan aktivitas vasodilatasi ekstrak etanol batang Fibraurea tinctoria Lour. Pertemuan Ilmiah Tahunan Nasional Perhimpunan Farmasi Kedokteran Indonesia. Universitas Kristen Maranatha, Bandung, 7-8 Mei 2011.

4. Ismail, ., and Kosala, K. 2011. Uji perbandingan aktivitas vasodilatasi secara in vitro pada dua jenis tumbuhan akar kuning famili Menispermaceae. Jurnal Kimia Mulawarman, Vol 8, Nomor 2.

5. Ismail, S., Mustofa, Ngatidjan, Susidanti, R. A. 2014. Aktivitsas vasodilatasi fraksi metanol daun Dracontomelon dao terutama dipengaruhi oleh endotel. Prosiding Peluang dan tantangan obat tradisional dalam pelayanan kesehatan formal dalam rangka Simposium Nasional tanggal $15 \mathrm{Mei}$ 2014. Diterbitkan oleh Bagian Farmakologi dan Terapi Fakultas Kedokteran Universitas Gadjah Mada, page 118-22.

6. Dong, U. L., and K.I., C. C. 1996. Calcium channel blocking and $\alpha-$ adrenoceptor blocking action of coptis rhizoma extracts and their alkaloid components in rat aorta. Arch. Pharm. Res., 19(6):456-61.

7. Vercruysse, L., Morel, N., Camp, J. V., Szust, J., and Smagghe, G. 2008. Antihypertensive mechanisme of the dipeptide Val-Tyr in rat aorta. Peptides, 29:261-7.

8. Boulanger, C. M., and Vanhoutte, P. M. 1994. The endothelium: a pivotal role in health and cardiovascular disease. France, Servier

9. Rapaport RM. 1989 Cyclic guanosine monophosphate inhibition of contraction may be mediated through inhibition of phosphatidyl inositol hydrolysis in rat aorta. Circ Res. 58:407-10.

10. Hofmann, F., Ammendola, A., and Schlossmann, J. 2000. Rising behind NO: cGMP-dependent protein kinases. J Cell Sci. 113:1671-6.

11. Ismail, S., dan Marliana, E. 2009. Aktivitas Antioksidan Daun Dracontomelon dao. Laporan Penelitian Bantuan Penelitian untuk Paten. Program Unggulan Berpotensi Hak Kekayaan Intelektual (UBERHKI) Dikti.

12. Xu HB and Huang ZQ. 2007. Vasorelaxant effects of icarin on isolated canone coronary artery. $J$ Cardiovasc Pharmacol, 49:207-13.

13. Naderali, E. K., Smith, S. L., Doyle, P. J., and Williams, G. 2001. The mechanism of resveratrol-induced vasorelaxation differs in the mesenteric resistance arteries of lean and obese rats. Clinical Science, 100:55-60.

14. Chiou, W. F, Chou, C. J., Liao, J. F., Sham, A. Y., and Chen, C. F. 1994. The mechanism of the vasodilator effect of rutaecarpin, an alkaloid isolated from Evodia rutacarpa. Eur J Pharmacol, 257:59-66. 